\title{
AUTHORITY PERCEPTION OF THE GROUPS WHICH MAINTAIN CUSTOMS OF BLOOD FEUD AND HONOR KILLING
}

\author{
Hasan Emir AKTAŞ 1
}

\begin{abstract}
Blood feuds and honor killings suggest a systematic and collective process of trial and punishment in tribal communities based on customary norms.

Customary murders usually occur in tribal groups in which central authority is either weak or totally absent. In the former case, tribal people experience a conflict between norms of the central state and those of the local group.

On the other hand, the acts of tribal groups violating legitimate legal and administrative system differ from similar unlawful acts, in that they are determined and justified by norms of the feudal group and they have been perpetrated deliberately and under the pressure of the group.

In this paper, first, connection of customary murders with tribal communities has been examined. Then the reasons and motives that drive them to those practices at the expense of violating legal system and central authority are considered.

It is seen that customary norms and "common honor and prestige" conception of tribal people form an identity and affiliation much more important than their allegiance to state.

Accordingly, any attempt to remove those devestating practices should consider penetration of legitimate authority of the state especially by educational and informative methods.
\end{abstract}

Keywords: Blood feuds; honor killings; tribal groups; authority perception; traditional customary murders.

\section{KAN DAVASI VE NAMUS CINAYETI TÖRELERINII UYGULAYAN TOPLULUKLARDA OTORITE ALGILAMASI}

\section{ÖZ}

Kan davaları ve namus cinayetleri kabile türü topluluklarda töre normlarına dayalı sistematik ve kolektif bir yargılama ve cezalandırma sürecini ifade etmektedir.

Bahsedilen bu töre cinayetleri genellikle merkezi otoritenin hiç bulunmadığı veya zayıf olduğu kabile/aşiret türü gruplarda gerçekleșmektedir. Belli bir kamu otoritesinin bulunduğu ama etkili șekilde

\footnotetext{
${ }^{1}$ Asst. Prof., Atatürk University, Faculty of Economics and Adminisrative Sciences, Department of Public Administration, hasanaktas@atauni.edu.tr.
} 
nüfuz edemediği durumlarda, aşiret mensubu olan insanlar merkezi devlet ile mahalli feodal grubun normları arasında bir çatışama yaşamaktadır.

Diğer taraftan kabile türü grupların meşru hukuk ve otoriteyi ihlal eden eylemleri, grubun normlarlyla belirlenmesi ve gerekçelendirilmesi, grubun baskısı altında ve bilinçli bir şekilde gerçekleşmesi yönleriyle kanunsuzluğa dayalı benzer hareketlerden ayrılmaktadır.

$\mathrm{Bu}$ çalışmada ilk olarak töre cinayetlerinin kabile/aşiret topluluklarıyla bağlantıları incelenmektedir. Daha sonra, bu toplulukları mevcut hukuki sistemi ve merkezi otoriteyi ihlal etme pahasina, bu cinayet eylemlerine yönelten sebep ve saikler değerlendirilmektedir.

Kabile topluluklarında töreye dayalı normların ve "müșterek şeref ve prestij" telakkisinin bu insanlar için devlete bağlllıktan çok daha önemli bir kimlik ve aidiyet oluşturduğu görülmektedir.

Bu itibarla, bu yıkıcı uygulamaları ortadan kaldırmaya yönelik bir teșebbüsün, devletin meşru otoritesini özellikle eğitim ve bilinçlendirme metotlarıla bu topluluklara nüfuz ettirmesi gerekmektedir.

Anahtar Kelimeler: Kan davası, namus cinayeti, aşiret toplulukları, otorite algılaması, töre cinayeti.

\section{Introduction}

Blood feud is an attitude that when a member of a tribe is killed by outsiders, all the other members try to take revenge from the killer or any other member of his tribe, by the feeling of solidarity and collective honor. Having become a traditional custom for some tribal groups, this practice is an event which might incite other sets of events and sometimes continue in mutual retaliations for generations.

As for honor killings, it is a social phenomenon that a female member of a tribe who is supposed to be involved in a sexual event, or a male who is believed to have a relationship with a woman (with her consent or not) are killed under the social pressure of the community in order to restore honor of the group.

As "honor killings" and "blood feuds" are usually based upon traditional norms and tribal rules, they can be considered under the collective category of "customary murders" (Aykut, 1999: 48-50). Because both of these types of events usually occur in traditional communities, in both of them, social pressure is felt, and in both, restoring the honor of the group is aimed. Of course these two types of illegal customs emerge in different sociological environments. For example blood feuds occur rather in communities of established feudal norms and authorities, whereas honour killings are perpetrated in places where tradition and current set of relations undergo a process of transformation. But anuyway they are both two practices carried out by feudally-motivated groups and individuals.

36 | Celal Bayar Üniversitesi Sosyal Bilimler Dergisi - Cilt: 13, Sayı: 3, Eylül 2015 
Some of the customary murders have occurred in a social and political environment which lacks a central public authority as in Arab population of pre-Islamic period. Whereas some others have been committed in territories under the sovereignty of a central state like in Kurdish population living in South Eastern part of Turkey. The fact that those customary murders are widely adopted and strongly accepted within the group, differentiates them from some individual reactions and unusual anomalies. Those acts thus become some penal sanctions perpetrated under the planned and desperate approval of the community. Accordingly the social groups that perpetrate these customs apply a legal, administrative and judicial system different completely from that of the state. As there is no officially approved and constitutionally confirmed autonomy, federalism or devolution here, the judicial and penal acts become unlawful.

When a group does not accept legitimacy of a state and rebels against it (in which case the situation will turn to be a civil war) it is understandable if that group does not recognize security forces and legal and judicial system of that state. In this case the separatist group will supposedly try to substitute some new legal bodies and forces of its own. Because all the institutions and laws of the existing political system will have lost their legitimacy for that group, in other words they will become null and void. If that group rebels not against a current government but against the political system itself, it will already be a paradox if they seek justice referring to laws and institutions of that state. As, if a political regime is considered illegitimate and invalid, it is rational and necessary to refuse the legal systems and judicial institutions as well, because they are simply no more than derived products of that political system.

But in some other cases, although some groups accept political and legal system of the state as legitimate, they can form and implement bodies and forces alternative to the official systems of the state. Underground gangs and feudal groups are two cases in which a separate judicial process and punishment act is implemented illegally in the territories under the sovereignty of a state and the related group accepts those acts as valid norms. Yet attitude of people belonging to underground gangs toward the state, its legal system and judicial bodies is quite a different matter. As people who are involved in this kind of organizations are aware that these acts are unlawful according to current and legitimate legal system; but in a sense these people have internalized a prohibited environment full of unlawful acts and affairs and they cannot live outside this environment, like drug addicts. Even many of those gang people may 


\section{Hasan Emir Aktaş}

commit crimes again when they are released after years of imprisonment either because they can't get out of vengeance feelings or they made committing crimes as inseparable part of their life and psychology. At such a point, incurring punishment in the prisons of the state becomes inefficient for their psychological rehabilitation and only vengeance methods of their own customs can satisfy them, relieving their tension.

Well, how can we explain customs like blood feud and honor killings usually maintained among tribe members? How can we understand these people's attempt to protect their own rights, to deter threats of the outsiders and punish aggressors, to restore their communal and familial honor themselves, despite authority, judicial courts, penal code, security forces and prisons of the state? When we compare this sort of unlawful practices of tribal groups to unlawful acts of underground gangs we can notice a substantial difference: Members of tribal groups are not in the pursuit of satisfying themselves by committing crimes. Those people who do not refuse obeying the law at least in principle despite that their acts constitutes a crime according to current judicial and legal systems of the state, commit these crimes in order to restore their honor, which they hold more important than obedience to laws. These people do not have an inclination to commit crimes which are not proscribed by their customs and even, according to traditions they are expected to observe some rules while they commit the customary crimes.

In tribal groups, although there is collective responsibility for the group members in both cases in which an assault is made by a group member on outsiders or a group member incurs an assault by outsiders, yet in practice there are certain criteria for determining who will be held responsible. Degree of kinship to the offender or victim is a substantial criterion for determining responsible group member(s). In blood feuds, degree of kinship to be used as criterion to determine who will bear the responsibility of the offensive group member or who will take revenge of the assaulted one, vary from one tribal society to another. For example in South Eastern part of Turkey, in Arab tribes all male relatives of the victim up to fifth level of kinship are held responsible for taking vengeance of the murder, whereas in Kurdish tribes this responsibility can reach up until the seventh level of ancestors. Besides that, age and gender factors also play a role in determining those who will be held responsible in the process of taking vengeance. In this regard, excluding the females, children and elders from the sphere of vengeance is a customary rule at least in principle (Ökten, 2010: 174).

38 | Celal Bayar Üniversitesi Sosyal Bilimler Dergisi - Cilt: 13, Sayı: 3, Eylül 2015 
Therefore, the fact that customary murders are limited by some rules and criteria under the customs of the tribal groups might be one of the substantial difference that separate them from the nolimit criminal acts of underground gangs.

\section{Communities}

II. Relation of Customary Murders with Tribal

When we look both at the practices in the past and the situations at present, we see that most of the blood feuds and honor killings occur in tribes and clans governed by traditional customs and rules. One of the examples in which blood feuds and systematic and perpetual vengeance acts are widely carried out in the past is Arabian society in the pre-Islamic period. In that society tribal structure and customs widely and effectively determined political, social and legal life.

Again when we look at more recent cases, we can see that most of the societies that carry out practices of blood feud and honor killing are the ones organized in tribal forms.

For example, South Eastarn part of Turkey in which honor killings and blood feuds most frequently occur is at the same time a region where feudal social structure and economic inequities are more prevalent and level of education is lower (Sarıhan, 1999: 60). Already feudal structure leads economic inequity, economic inequity causes lower level of education for most of the people and lower level of education in turn helps the feudal structure to survive with its rules and bodies.

Another example is today's Iran. Although honor killing are committed throughout Iran, it is generally assumed that collective and ritual honor killings are not a traditional action among Persians or in Persian-dominated areas. That is, social environment in those areas does not exert pressure on men to kill their female relatives who are assumed to have broken traditional code of honor. Although conservative groups of the society might tolerate violence on women to an extent, there is no traditional expectation among Persians that family honor must be restored by violence. The material provided shows that honor killings primarily occur among tribal peoples such as Kurdish, Lori, Arab, Baluchi and Turkish speaking tribes. These groups are considered to be more traditional and conservative than Persians, and discrimination against women seems to be deeply rooted in tribal culture. The majority of these groups are Sunnis living in the socioeconomically less developed and geographically more isolated areas of Iran (Landinfo, 2009: 7).

Arab societies today which apply customary murders also show characteristics of a society that maintain a form of tribal life in 


\section{Hasan Emir Aktaş}

steppes and deserts (Emiroğlu \& Aydın, 2003: 60). Although tribal ties among Arabs have relatively weakened in recent years, yet influence of feudal social structure there is more alive than in other societies. And as a result of this fact, it seems that honor killings are at a higher level in Arab societies compared to other groups. For example in Egypt 52 honor killings have been reported for 1997 (Yıldız, 2008: 218).

As this paper studies authority perception of the societies which maintain customary murders we can divide them in two groups by whether there is a state exerting sovereignty over their territories or not.

\section{A. The Communities which are not Controlled by a}

\section{Central State Authority}

Pre-Islamic Arab population can be one of the best examples for the societies in which tribal structure prevails, blood feuds are systematically perpetrated and a central political authority is absent.

Unlike in Greek and Roman societies, in the pre-Islamic Arab society political and administrative institutions were not developed. Moreover there were no written legal texts like constitutions and laws to regulate their social life. They lacked a culture and tradition of a state. So in Arabian Peninsula there was not a state which would bring Arabs together under a centralized political authority. They lived in scattered tribes. They were not subject to a common law and a judicial body (Hasan, 1973: 73).

Pre-Islamic Arab society refused authoritarian political structures and emerged as a society based on tribal and familial organizational forms which esteemed personal bravery and prestige. The chieftain commanded the battles between tribes as well as assumed role of an arbitrator in the disputes between tribe members. But despite these authorities, he did not have a capacity to force families under his control to protect his position or to impose his power on them. Since there was not a collective and common judicial authority, the order between tribal groups was established through blood feuds in the form of retaliation. If a member of a tribal group was assaulted by an outsider, the act was considered as committed against all members of the group rather than against the offended person only: the offended group retaliated the act in equal terms but if the group saw themselves higher than the offending group and sought to restore their honor, the act could be more severe. But if the retaliation was considered extreme by the other group, who in turn aimed to restore their honor, they could also retaliate by a counter act, thus leading the blood feud to become a circle of retaliative murders (Hodgson, 1993: 87).

40 | Celal Bayar Üniversitesi Sosyal Bilimler Dergisi - Cilt: 13, Sayı: 3, Eylül 2015 
All members of a tribe considered themselves of the same blood. In Arabia before Islam, blood feuds determined the limits of an effective kinship. A kindred group was one that did not hold a blood feud inside it. If someone killed a person from his own group, he never received backing from any member of his group. He would either be killed or he would be outlaw, taking refuge in an outsider group. But if the slayer and the slain belonged to different groups, a blood feud emerged and anyone from the tribe of the slain could take vengeance from the tribe of the slayer (Smith, 1907: 25).

In such a system, the basic kinship group is determined according to whether they act together in the case of blood feuds. In the Early Arabia this basic group was not family or the circle of relatives as we understand today. It was rather a tribe having a certain name. To determine if someone is involved in a blood feud, it was sufficient to look if he shared the same tribe name with the victim or offender. Tribe members of the victim wouldn't say "That man's blood is spilt". They would rather say "Our blood is spilt." Of course, father, brother or son of the slain felt desire for vengeance more than some distant relatives. But this fact wouldn't affect the rules of the blood feud. No member of the group could escape the responsibility, just because he was not close relation of the slayer or the slain. Therefore in Arabic society, kinship is sharing a common blood. That is, it was tribal tie based on blood tie which united people of the same group and gave them collective duties and responsibilities and no member of the tribe could withdraw responsibilities of this tie (Smith, 1907: 26-27).

But unlike pre-Islamic Arabs, some other ancient societies like Ancient Egypt, Mesopotamia, Ancient Turks, Jewish people, Romans and Christians did not retaliate cases of murder as a blood feud, because there were a central authority and official judicial institutions in those societies (Köroğlu, 2011: 310-314).

So, one of the basic reasons of the fact that blood feuds were widely applied in tribal societies was to fill the gap of control and security arising from the lack of a central authority.

For example for Bedouin Arab populations blood feud has been a tradition which has provided security for a nomadic people living in tents, without protection of solid buildings in the sparsely populated desert; and they have been vulnerable to attack by others; and they have not had access to modern police or courts (Al-Krenawi \& Graham: 1997).

In Arab societies, blood feud is not an individual matter, undertaken by a person in an emotional and reactionary psychology. 


\section{Hasan Emir Aktaş}

It is rather a kind of a collective guarantee provided by the group to its members (Jabbur, 1995).

We should also mention that Islam has radically forbidden and abolished blood feuds. According to Islamic Law, groups and persons other than the state do not have right to implement penal sanctions. For example, Old Testament which is the primary reference of Jewish law, prescribes that the avenger of blood (heir of the slain) himself should kill the slayer under the principle of retaliation (Old Testament, 35/19), ${ }^{2}$ whereas Islamic law although allows relatives of the slain to decide the execution or pardon of the slayer, but it confers the authority to execute the murderer only to the state (Quran, 2/78).

B. Tribal Communities which Stand Under the

\section{Sovereignty of a Central State}

In the case of some tribal groups today, like in South Eastern part of Turkey, some regions of Iran which are organized in the form of tribes and some regions of Israel inhabited by Arab population, on one side exists legitimate and a sovereign central state, but on the other side tribal groups try to establish justice on their own, to give a ruling at least on some events referred in their customs and to execute the murderers by themselves.

This practice which can be referred as "a state within a state" or "a law within a law" suggests a situation which deserves to be examined with respect to their authority perception. What social, cultural and psychological reasons and motives drive such a group which in fact continue to accept the central state as legitimate to implement an alternative system, ignoring the state's exclusive authority to judge, deter, punish or acquit anyone under its sovereignty?

Actually, the fact that communities apply sanctions and pressure against those violating the established social norms can be witnessed in most of the traditional societies largely, and in modern societies partially. Social control, one of the important issues of sociology, refers to all of the mechanisms and instruments used by the society or social groups to maintain the social order and to stop deviations, promoting the processes which help the society to operate in a harmony (Dönmezer, 1982: 286).

Thus, standard patterns of action are formed within the society. Those who do not act in the expected patterns are accepted

\footnotetext{
2 The avenger of blood is the one who shall put the murderer to death; when they meet, the avenger of blood shall execute the sentence.
}

42 | Celal Bayar Üniversitesi Sosyal Bilimler Dergisi - Cilt: 13, Sayı: 3, Eylül 2015 
as deviated and face social control mechanisms, which are applied to maintain order and stability (Anık, 2011: 104).

But blood feuds and honor killings suggest an action which has serious results as destroying one's life completely, going far beyond the social and psychological pressure to maintain social control. Therefore, while social pressure which stands within some limits doesn't conflict with legal order of the state, customary murders suggest a substantial and fundamental challenge to the public authority and legal system.

\section{B.1. Blood Feuds in Tribal Groups and Possible Reasons}

In the Middle East "Asabiye" (kinship and tribal solidarity), as Ibn-i Haldun conceptualized it, is a prevalent practice. By this solidarity, group members can protect each other and make efforts for each other. This solidarity makes the group stronger and more deterrent against its rivals and enemies. This phenomenon emerges rather in kinship groups of close relations. Here a member's affection and loyalty for his/her family and tribe is of primary consideration. These kinship ties are shaped within the concept of "brotherhood partnership". "Blood feud" is an important aspect of this partnership. If any of the fellow members of the group is murdered by an outsider, the murderer should be killed. If a member of their own group kills a member of another group, other group would have right to take vengeance (Lindholm, 1996: 51-55).

Taking vengeance is a pattern of action frequently witnessed between tribes which are in a permanent power struggle against each other. The ability to take vengeance is seen as a sign of power, honor and nobility and a group unable to take its vengeance is supposed to lose physical and moral power and to be humiliated in the eyes of their rivals. Ökten writes that an old man, one of the people he interviewed researching blood feud in South Eastern Anatolia said him that "here whoever is stronger, he becomes the winner". In the blood feud cases in the region, weaker group would not dare to confront more crowded and powerful groups. In such situations, weaker groups either confront the powerful one, taking the risk of being killed, or leave their hometown to avoid losing everything (Ökten, 2010: 171).

Although authority of the state which assumes exclusive right to implement sanctions and punishments operates to an extent in the region, blood feuds continue to be widely carried out. Even if the state finds out the perpetrator of a murder and punishes him, vengeance is not supposed to be taken if the offended group do not punish the offender themselves. Because if the group whose "blood is spilt" does not "clean his blood", it will go on "bleeding" and its honor 


\section{Hasan Emir Aktaş}

and prestige will be harmed in the neighboring society. It is supposed that in such a situation prestige of those groups will be damaged, they will not be considered seriously by other groups and they will experience an important loss of position in the power competition (Ökten, 2010: 171).

In the interviews Ökten carried out in the region with people from tribal groups, they stated that if a group once loses prestige, they will fall behind other groups with regard to social and moral status, and in that case they will be disregarded and left in a difficult position in all areas of life. One of the aggrieved persons stated that: "Once you are known as one who could not take his vengeance, you will lose everything. Everyone will dare to assault you, your lands and watering turn will always become at risk. When taking or giving bride, people will take this into account. Even your girls married to other groups might face reproaches arising from this situation (Ökten, 2010: 172)

In tribal societies individuals and families must avoid any perception of weakness, as impression and reality are considered to be closely linked (Rieder, 1984: 138). Deterrence expected from blood vengeance is based on the thought that potential offenders would know that if they kill someone, they will expose themselves, their family, their clan or tribe to the unpredicted threat of group vengeance that might menace generations of the group (Ginat, 1987).

In societies which tend to stand outside legal structure, there is a remarkable conflict between honor and legality. Because, if such a group goes to law for the redress of right, they will have confessed publicly that they have been treated wrong. In this case, demonstration of the group's vulnerability to outer offenses will place its honor in jeopardy. In such a situation, that the wrong is compensated in the hands of a legal authority hardly redeems the honor. Moreover, delays of court procedure give the offensive group the chance to assume humiliating attitudes towards the offended group, thus risking advertising its plight instead of restoring its honor. Therefore nemo me impune lacessit (No one can harm me unpunished) is a favorite motto not only for aristocracy but for all groups who have such a conception of honor (Pitt-Rivers, 1966: 3031).

\section{B.2. Honor Killings in Tribal Groups and Possible Reasons}

Honor conception in the Middle East especially for males is closely related to bravery, independence, generosity, hospitality, blood vengeance and female chastity. Honor is not an individual matter but it has rather a close connection with the paternalistic community where male and female live (Lindholm, 1996: 13).

44 | Celal Bayar Üniversitesi Sosyal Bilimler Dergisi - Cilt: 13, Sayı: 3, Eylül 2015 
Honor killing is a killing or injuring act committed by family members against a female relative, when they believe she has brought shame on the family. That action usually includes the killing of the male as well who is involved in a sexually-interpreted relationship with that female.

A woman can be target of honor killing for a variety of reasons including refusing to accept a planned marriage, being the victim of a sexual assault, seeking divorce or committing adultery. Honor killings can also target those who make lovers or spouses from members of a group other than her own religious or ethnic group (Smartt, 2006: 4).

One of the major differences between domestic violence and honor killings is that the latter involve the collective decision of the whole family including mothers and senior females. Mothers and other female elders for example hide and turn a blind eye to and even sometimes encourage honor crimes or tortures. Because all the family members think women as an inseparable part of a collective body rather than a separate individual (Smartt, 2006: 5).

In the honor killing cases that occurred among migrant (mostly Muslim) Asian populations dwelling in Europe, defendants in Western criminal courts try to justify their acts on the grounds of customary norms and moral conformity (of the woman). Accordingly, they seek mitigation by the argument that the murder was committed as a result of the need to defend or protect the honor of the family (Smartt, 2006: 5).

In the honor killings committed in Turkey, there is gender discrimination in the perception of "honor cleansing". When male members of a tribal group do the same actions which can cause murdering of females on the grounds of honor killing, the notables of his tribe does not need to apply him such a punishment (Tezcan, 2003: 46-48).

This gender discrimination in chastity perception demonstrates that essentially honor killings are based on tribal rather than religious motives. Because in the traditional tribal structure, male members, especially chieftains, establish for themselves a privilege and hegemony, which would not be allowed by Islam. Moreover, when a daughter whose parents force her to marry someone without consent run away with another boy she loves and they get married soon, the family might kill the couple on the ground of "cleansing honor". This fact also shows that the matter is related to tribal conception rather than religious principles. Because forcing a person to marry someone is inconsistent with Islamic principles. Furthermore, in Islamic law, consent of the parties 


\section{Hasan Emir Aktaş}

getting married is a primary condition for validity of marriage and without that condition a marriage would be invalid. Whereas traditional tribal conception makes it a matter of restoring honor if not "cleansing honor" for a family if their daughter get married to someone without their consent. Traditional authority considers any lack of obedience of woman, a fatal disrespect and contumacy. So she is expected to obey her male relatives and tribal customs in all conditions.

In addition to that, in the societies where traditional culture prevails, when women are assaulted including the passing a word at them, reaction of the local groups might be sudden and severe. When honor of the family is a matter of fact, group members usually become ready for self-sacrifice (Ünsal, 1995: 103). Therefore the events which involve women and sexuality can cause either honor killings in which women are punished or it can cause murdering of the assaulter, which in turn can make this murder first ring of a longlasting chain of a blood feud.

"Honor-related violence and honor killings are welldocumented in Pakistan, among Kurdish communities in Turkey and Iraq, among Palestinian population and among immigrant communities in a number of European countries" (Landinfo, 2009: 5).

\section{Internal and External Authority Perception of the Groups that Maintain Customary Murders}

No doudbt, a state's exercising political, administrative and legal control over the territories under its sovereignty is significant for unity, order and stability in the country as well as for the rights and freedoms of the individuals. Making law, assuming functions of defense, security, judiciary and punishment are some of the duties and authorities that a state cannot share with private persons or associations. For example, a state can transfer the duty of cleaning the streets to some private persons or groups under the system of decentralization, but it can never transfer power of punishment to any part.

If a private part, not the state inflicts a sanction on an alleged offender, the link between the state's judgments regarding the wrongfulness of action and the appropriateness of the sanction will be severed at the stage that the suffering is inflicted on the criminal. When a private individual inflicts a punishment, this person and not the state will judge and determine the way and severity of the sanction. Therefore a just and equitable state cannot approve, encourage or initiate the infliction of a sanction on an alleged offender on the basis of private judgment. As such an approval and

46 | Celal Bayar Üniversitesi Sosyal Bilimler Dergisi - Cilt: 13, Sayı: 3, Eylül 2015 
application might give an arbitrary weight to the judgment of the private individual who inflicts the sanction (Harel, 2009: 136).

Hart divides the rules that govern a society into two categories: primary and secondary rules. Primary rules are standard modes of behavior that group members are obliged to obey. Secondary rules are more formal, established and systematic legislature that can regulate the sophisticated, detailed and differentiated problems of a complex and developed society. For him a society which is small and "closely knit by ties of kinship, common sentiment and belief" can be regulated by primitive rules with no need for a set of secondary rules. But if a society is larger and more complex than that, a set of secondary rules must supplement those primary rules and remedy their defects (Hart, 1961: 89-90).

Moreover, a community in the form of a tribe cannot go on living in the modern period in a closed society. They must be part of a larger society. Already fast spreading of the modern communication technology will force local groups at least at younger generation level to integrate to broader society. After a while the older generation who refuse to open their society might even face a conflict with their younger generation. So, in order to be a part of a larger society, they must adopt and apply a more comprehensive, developed and detailed legal and judicial system.

However, an important feature of the groups which maintain blood feuds is that their allegiance to the state is quite weak. This lack of allegiance is both in the sense that they do not accept effect of the binding legal norms and also in the sense that they do not confine power to provide justice and security to public authorities.

What conclusions can we reach when we compare anarchism and lack of allegiance of the blood feud groups to legal norms and judicial and security authorities of the state?

Let's look at a brief definition of anarchism "Anarchism has been defined in numerous ways. Negatively, it has been defined as the rejection of rule, of government, of the state, of authority, of society, or of domination. Less frequently, it has been defined positively as a theory of voluntary association, of decentralization, of federalism, of freedom, and so on" (McLaughlin, 2007: 25).

Whether anarchism is taken in its positive or negative sense, it is impossible to draw an analogy between anarchism and feudal structures which lay grounds for blood feud. If taken in positive sense, anarchism refuses not only legal system and authority of the state, but also all forms of authority at the societal level on the grounds of liberating from all kinds of pressure and hegemony. As for feudal structures, even though they do not recognize public 
authority, they accept much more irrational authority of the customs and feudal chieftains and much more restricting pressure of their community.

If we take anarchism in its negative sense, again we can't compare it to feudal authority perception. Although some anarchist approaches accept formation of associations at civil society level in place of public authority, their formation with the willing and deliberate participation of people constitutes one of their basic and indispensible features. Whereas in feudal structures, as customs are strict and static, feudal authorities are closed to change and society make social and cultural norms a pressure on group members, feudal norms and authorities here are quite different from the role that anarchists attribute to voluntary associations as alternative to public authority.

Actually anarchists and Thomas Hobbes attribute exactly opposite functions to public authority. Just at this point, is it possible to place the feudal structure where customary murders occur, in the thought and system of Thomas Hobbes?

Thomas Hobbes states that people have equal desires to reach their goals and therefore when they try to obtain the same things, hostility will emerge among them. So in the conditions of nature which lack a sovereign law and authority, all the people will fight each other and try to destroy each other. In such conditions no one will be safe including the most powerful ones. That who is physically more powerful cannot guarantee that weaker people will not offend him resorting to cunning or cooperating with others.

For Hobbes, in such conditions full of uncertainty and danger, neither agriculture and trade nor science and art will have suitable environment to prosper. As there is no law and norm in this situation, neither justice nor ownership will be a matter. Unless there are laws forbidding offensive acts of people arising from their desires and ambitions, these desires cannot be claimed unlawful.

For Hobbes,

Though there had never been any time wherein particular men were in a condition of war one against another, yet in all times kings and persons of sovereign authority, because of their independency, are in continual jealousies, and in the state and posture of gladiators, having their weapons pointing, and their eyes fixed on one another; that is, their forts, garrisons, and guns upon the frontiers of their kingdoms, and continual spies upon their neighbors, which is a posture of war (Hobbes, 1651: 79).

So this condition shows that those sovereign powers are in distrust, suspicion and fear against each other.

48 | Celal Bayar Üniversitesi Sosyal Bilimler Dergisi - Cilt: 13, Sayı: 3, Eylül 2015 
According to Hobbes, human beings must ultimately get rid of this condition full of fear, chaos and danger. Otherwise they are exposed to destruction. Reason and feelings of human being drives him to peace. Therefore there is no way out other than agreement among human beings. The first step in this regard is that everyone should accept to obey natural laws in the sense that they accept not to give harm to others. But as people have uncontrolled desires, there is no guarantee that they will comply consistently with those natural laws. Then formation of a concrete and effective power and authority which will force people to live in an order and will frighten and punish them is necessary. For Hobbes, this irresistible hegemonic and coercive force will be the state (Hobbes, 1651: 76-88; Göze, 2011: 149-152).

Anarchists and Hobbes attributed completely opposite roles to state and individual. Anarchists suppose that public authority has a malicious characteristic, it treat individuals and civil groups arbitrarily and uncontrolled and it is repressive and restrictive but individuals are rational, temperate and conscious. Whereas Hobbes considered that individuals are in a constant rivalry and conflict and they have a potential to harm each other by the motives of acquiring, safety and hegemony, but state is an authority of justice and security which will transform the state of chaos, war and violence into peace and order.

How can we compare tribal structures that lay grounds for blood feuds and Hobbes's remarks explaining nature of individual and society and significance of public authority? It should be noted that whether in societies where there is not a higher state authority apart from tribal structures, like in pre-Islamic Arab society, or in societies where there is a central state authority but allegiance of tribe members to public law and authority is weak like in some current Kurdish and Arab groups, inner structure of a tribe is completely different from Hobbes's natural state of savagery. Because within the structure of a tribe, there is a set of customs instead of a legal system, and there is a feudal organization instead of an administrative authority. Tribal leadership and social control rule together and anyway there is a certain order and security within the tribal group even though it is closed to change and rational design and deprived of some basic human rights standards.

We can also compare and contrast authoritarian systems and the order which is established by tribal leadership and social control based on customs. The similarity is that both of them provide certain order and security, although they lack a standard of basic rights and freedoms. And one of their substantial differences is that in 


\section{Hasan Emir Aktaş}

authoritarian systems, it is the ruling leadership which design laws and policies. The leadership can make changes in legal and administrative norms whenever they deem it necessary. Therefore in authoritarian structures, the norms are open to change at the discretion of authoritarian leadership even though these changes might not be based on rationality and rule of law. Whereas in feudal structures based on traditional rules, change in those norms usually becomes slower and harder. Here the function of making irrational and repressive norms which are assumed in the authoritarian system by the leadership is realized by traditional customs, and tribal leadership and social control adopt these norms without any objection and apply them as they are.

In fact as these traditional rules have been formed by the preferences of the previous ruling elites which had once laid the foundations of the feudal structure, they serve today interests of the same privileged and powerful groups as in the past. According to these feudal rules and norms, women should obey men, younger people should obey the older ones, the poor should obey the wealthier, and the lower in the social strata should obey those of nobility and higher status. Therefore although feudal structures and authoritarian systems are similar in the sense that in both systems current norms serve the interests of ruling and hegemonic groups, ruling elites of feudal systems do not want to modify current norms.

Because in order to make norms more effective and binding, they need to be attributed inviolability and sanctity. In feudal structures, the leadership does not have a wide armed force to help maintain the operation of the system as in authoritarian systems. And already a wide armed force requires an organized tax collection system and in turn a systematic tax collection process requires capacity of a wide armed forces, such a stage refers at the same time to a point of difference between feudal structure and state.

Therefore as the authoritarian systems usually have capacity of a state, they employ an armed force to put norms and rules into effect even if they are renewed and changed.

It is possible to make a comparison between Hobbes's natural state of conflict, chaos and danger and relations between different tribes rather than between members of the same tribe. As customary systems of rules in primitive societies maintained internal order even when violence and warfare characterized relationship with other groups and communities (Benson, 1989: 21). At this point we see that tribes are involved in decades-long warfare and almost all members of a tribe can target any member of the hostile tribe,

50 | Celal Bayar Üniversitesi Sosyal Bilimler Dergisi - Cilt: 13, Sayı: 3, Eylül 2015 
putting them in danger and uncertainty. In this case, the conflict and fight occur between the groups rather than the individuals.

It was stated above that tribes must be powerful and take their avenge themselves in order to survive and protect their prestige. In other words, in their mutual relationships tribal groups have to fight and kill in order to survive and keep their honor. Just this aspect of tribes can be compared to savage relationships Hobbes supposed to occur among individuals in the state of nature. Therefore, as state authority is necessary to put an end to violent relationships between individuals, a central state authority and its laws must be enforced in order to remove violent relationships between tribal groups. Even we can take the matter a bit further and suggest that an international organization which should be sufficiently effective and comprehensive (more effective of course and equitable than the UN) can be established in order to minimize international fears and tensions which cause rulers and states to keep armies and carry out military exercises as Hobbes observed.

Of course the fact that feudal groups mutually accept certain rules such as not targeting women, children and old people in their conflicts, doesn't mean that these people are free from chaos, threat and fear. Because even if women, children or old people are not targeted themselves, the fact that their closest male relatives are in danger is enough to upset their lives.

In a survey conducted for youngsters of Arab community living in Israel, it has been found out that young people are under a remarkable psychological stress, even though their families' wellfunctioning might help them to deal with stressful and traumatic events (Al-Krenavi et al., 2001: 466).

On the other hand it is a psychological reality that if an individual experiences a stressful and traumatic process, it is likely that he will either have psychological vulnerability or will internalize the violence and vengeance, losing the capacity of questioning such a violent social conduct, which will contribute only to its maintenance.

We can also compare connections between a tribal group and its sovereign central state to federal and confederal structures. Actually the most substantial difference between feudal structures and federal and confederal systems is that while in the latter the political power is transferred legally and constitutionally from central state to regional administrations, in the former the use of political and judicial power is based essentially on a de facto situation. If we compare federal and confederal systems to each other, we see that in the former at least in terms of legal hierarchy, the superiority is with the central authority, whereas in the latter the 


\section{Hasan Emir Aktaş}

central organization is held rather weak and loose and almost all of the political power stands at the hands of the member states.

Whether the control of the central state over tribal groups resemble the control of federal central authority or confederal central organization depends on power, politics, efficacy and penetration of the central state rather than attitude and structure of tribal groups. Feudal structures tend to be autonomous by their nature. They tend to fill in all the authority gabs that the central state leaves behind. Because they are based on social culture of the tribal group and they have a deep-rooted and comprehensive structure. Therefore as long as the central state penetrates the local group and weakens the influence of the feudal structure with its legal coercive tools and administrative apparatus as well as by the means of education and media, a transformation might occur from confederal to federal-type control system and even from there to a unitary structure.

\section{Conclusion}

Blood feuds and honor killings refer to a judicial and penal process alternative to official legal system, based on traditional tribal organization and customary rules. These two practices, although having certain differences of course, can be combined under a common category of "customary murders", as they both try to constitute a systematic and established alternative to legitimate judicial and penal authority of the state.

As blood feuds and honor killings are widely-accepted and "normalized" desperate practices rather than individual and exceptional reactions and sociological anomalies in the applying groups, the perception of the people living in those groups about the legal and judicial system of the state deserves attention. It is noticed that blood feuds are applied either in societies which lack a central state authority and a binding and comprehensive legal system like in pre-Islamic Arab population, or in societies where legal and judicial systems of an existing central state cannot penetrate the local groups thoroughly like in South Eastern part of modern Turkey.

Although the groups which maintain practices of customary murders can be compared to anarchists, political rebels and separatists, underground gangs in terms of that they do not comply with the law and order of the state, and again to federal, autonomous and confederal systems in terms of that local body implements a separate judgment and punishment process, they are yet different from all of these models.

The main factors which underlie blood feuds and honor killings are to restore or cleanse the honor of the tribe or related 
family members. Honor and prestige of the tribe is also considered as the source of its power and deterrence. Therefore, the members of feudal groups in which kinship relationships prevail, feel obliged to maintain customary murders not only to restore their honor in the moral sense, but also to preserve their power, influence and superiority in the sociological and political sense.

In addition to that, most important difference of the customary murders in tribal groups from avenge murders in the form of an individual reaction is that they are committed systematically and desperately with the acceptance and even pressure of the related group members. Accordingly, in the former cases, sociological and cultural factor is more influential than psychological motive. Therefore, tribe members who commit blood feuds and honor killings feel obliged to do so in order to get rid of the interior pressure of the tribal group as well as to preserve prestige and power of his tribe in the face of rival groups.

As blood feuds and honor killings in feudal groups have rather social and cultural character, in an attempt to abolish those practices, central states should consider especially weakening the local groups' allegiance to feudal authorities and customs and integrating them to the central state, to the remaining part of the society and to overall people of the world through education and information, in addition to penetrating its authority through all local groups by some administrative and security instruments.

Another factor for perpetration of especially honour killings is the changing social environvents of the local groups which migrate to and settle in big cities. In this case, economical burdens, soacial changes and cultural crisis can drive family members to conflict. For the handling of this problem again, the central state should prapere and implement social and economic programs for the integration of migrant local groups to urban conditions.

\section{BIBLIOGRAPHY}

AL-KRENAWI, Alean \& GRAHAM, John R. (1997), "Social work and blood vengeance: the Bedouin-Arab case", British Journal of Social Work, V. 27, pp. 515-528.

AL-KRENAVI, Alean, et al. (2001), "Psychological responses to blood vengeance among Arab adolescents", Child Abuse \& Neglect, V. 25/4, pp. 457-472.

ANIK, Cengiz (2011), “Toplumsal Zihniyet Aracılı̆̆ı ile Sosyal Kontrol”, Uluslararası Güvenlik ve Terörizm Dergisi, V. 2/1, pp. 101115. 
AYKUT, Oktar (1999), "Namus ve Töre Cinayetlerinin Türk Hukukundaki Uygulaması", Töre Cinayetleri, T.C. Basbakanlık Kadının Statüsü ve Sorunları Genel Müdürlügü Yayınları, Ankara, pp. 45-57.

BENSON, Bruce L. (1989), "Enforcement of Private Property Rights in Primitive Societies: Law Without Government", The Journal of Libertarian Studies, V. 9/1, pp. 1-26. Ankara.

DÖNMEZER, Sulhi (1982), Sosyoloji. 13. Ed., Savaş Yayınları,

GINAT, Joseph (1987), Blood dispute among the Bedouin and rural Arab in Israel: revenge, mediation, outcasting and family honor, University of Pittsburgh Press, Pittsburgh.

GÖZE, Ayferi (2011), Siyasal Düşünceler ve Yönetimler, Beta Yayıncılık, İstanbul.

HAREL, Alon (2009), "Why Only the State May Inflict Criminal Sanctions: The Case Against Privately Inflicted Sanctions", (ed.) Paul H. Robinson et al., Criminal Law Conversations, Oxford University Press, Oxford.

HART, Herbert L. A. (1961), The Concept of Law, Clarendon Press, Oxford.

HASAN, Hasan İbrahim (1973), Siyasi Dini Kültürel Sosyal İslam Tarihi, (tr.) İsmail Yiğit et al., V. 1, Kayıhan Yayınları, İstanbul.

HOBBES, Thomas (1651), Leviathan, London. (Prepared by Rod Hey for McMaster University Archive of the History of Economic Thought). İstanbul.

HODGSON, M. G. S. (1993), İslam'ın Serüveni, V.1, İz Yayınları,

JABBUR, Jibrail S. (1995), The Bedouins and the Desert: Aspects of Nomadic Life in the Arab East,. State University of New York Press, New York.

KÖROĞLU, Mehmet (2011), "Hukuk Tarihi Açısından Ölüm Cezası ve İnfaz Şekilleri”, İslam Hukuku Araştırmaları Dergisi, V. 17, pp. 309-322.

LANDINFO (2009), Report - Honour Killings in Iran, Country of Origin Information Center, Norway.

LINDHOLM, Charles (1996), The Islamic Middle East: A Historical Anthropology, Blackwell Publishers, Oxford.

MCLAUGHLIN, Paul (2007), Anarchism and Authority, Ashgate Publishing Company, Hampshire.

PITT-RIVERS, Julian (1966), "Honour and a social status", (ed.) John G. Peristiany, Honour and Shame: The Values of Mediterrnean Society, Weidenfeld and Nicolson, London.

54 | Celal Bayar Üniversitesi Sosyal Bilimler Dergisi - Cilt: 13, Sayı: 3, Eylül 2015 
RIEDER, Jonathan. (1984). "The social organization of vengeance", (ed.) B. Donald, Toward a general theory of social control: fundamentals, V. 1, Academic Press, Toronto, pp. 136-148.

ROBERTSON, Smith W. (1907), Kinship and Marriage in Early Arabia, Adam and Charles Black, London.

SARIHAN, Senal (1999), "Namus Cinayetlerinde Avukatların Sorumlulugu", Töre Cinayetleri, T.C. Basbakanlık Kadının Statüsü ve Sorunları Genel Müdürlügü Yayınları, Ankara, pp. 59-69.

SMARTT, Ursula (2006) "Honour Killings", Justice of the Peace, V. 170, pp. 4-7.

ÜNSAL, Artun, (1995) Kan Davası, (tr.) Niyazi Öktem \& Emre Öktem, Yapı Kredi Yayınları, İstanbul.

YILDIZ, M. Cengiz (2008), “Türkiye'de Töre Baskısına Bağlı İntiharlar ve Töre Cinayetleri", Izzet Baysal Üniversitesi Sosyal Bilimler Enstitüsü Dergisi, V.1/16, pp. 209-231. 


\section{Hasan Emir Aktaș}

56 | Celal Bayar Üniversitesi Sosyal Bilimler Dergisi - Cilt: 13, Sayı: 3, Eylül 2015 